\title{
Workshop Pembuatan Media Pembelajaran Listrik Magnet dari Barang Bekas untuk Meningkatkan Kompetensi Mahasiswa Calon Guru Fisika
}

\section{The Training on Making Electromagnetics Media from Waste Materials to Improve Competency of Prospective Physics Teacher}

\author{
Lalu A. Didik* \\ Prodi Tadris Fisika, Fakultas Tarbiyah dan Keguruan, Universitas Islam Negeri Mataram \\ Email: laludidik@uinmataram.ac.id
}

\begin{abstract}
Abstrak
Telah dilakukan workshop pembuatan media pembelajaran berupa generator listrik dan motor listrik berbahan dasar barang bekas kepada mahasiswa calon guru fisika. Peserta pelatihan adalah mahasiswa Prodi Tadris Fisika semester V yang merupakan calon guru fisika. Metode yang dilakukan dalam penelitian meliputi sosialisasi, pelaksanaan berupa pemberian materi tentang generator dan motor listrik, pendampingan pembuatan media pembelajaran, presentasi peserta dan evaluasi. Hasil pelatihan berupa media pembelajaran fisika yaitu generator listrik sederhana dan motor listrik. Evaluasi melalui angket menunjukkan bahwa $100 \%$ peserta setuju kegiatan pengabdian ini sangat bermanfaat dan $98 \%$ pesrta setuju metode kegiatan sudah sesuai. Namun $15 \%$ peserta kurang setuju mengenaia manajemen waktu karena alokasi waktu yang diberikan untuk proses pembuatan media pembelajaran dirasa masih kurang
\end{abstract}

Kata kunci: Media Pembelajaran, Generator Listrik, Motor Listrik, Barang Bekas

\section{Abstract}

A training on making learning media has been carried out in the form of electric generators and electromotors based on waste materials to prospective physics teacher. The training participants were students of the fifth grade of physics educations programs. The methods carried out in the study included socialization, implementation in the form of giving material about generators and electromotors, assistance in making learning media, participant presentations and evaluations. The training results are simple electricity generators and electromotors. The questionnaire evaluation showed that $100 \%$ of participants agreed that this service activity was very useful and $98 \%$ of participants agreed that the activity method was appropriate. However, $15 \%$ of participants disagreed with time management because the time allocated for the process of making learning media was still lacking.

Keywords: Media, Electric Generator, Electromotor, Waste Materials

\section{PENDAHULUAN}

Perguruan tinggi sebagai salah satu institusi yang ada di Indonesia mengemban amanah untuk menjawab tantangan zaman. Dalam hal ini perguruan tinggi harus mengupayakan dan menjadikan dirinya sebagai pusat pengembangan dan penyebarluasan IPTEK serta mengupayakan penggunaannya untuk meningkatkan taraf kehidupan masyarakat. Yang mana ketiga hal tersebut termaktub di dalam Tri Dharma Perguruan Tinggi.

Keberadaan perguruan Tinggi mempunyai kedudukan dan fungsi penting dalam perkembangan suatu masyarakat. Proses perubahan sosial yang begitu cepat di masyarakat, menuntut agar kedudukan dan fungsi perguruan tinggi benar-benar terwujud dalam peran yang nyata. Melalui dharma pengabdian masyarakat, perguruan tinggi diharapkan melakukan pelayanan masyarakat untuk ikut mempercepat proses 
peningkatan kesejahteraan dan kemajuan masyarakat. Selain itu, perguruan tinggi juga akan memperoleh feedback dari masyarakat tentang tingkat kemajuan dan relevansi ilmu yang dikembangkan.

Problem yang terjadi di masyarakat khususnya di madrasah-madrasah adalah perencanaan dan implementasi pembelajaran yang dilakukan oleh guru secara umum masih dilandasi metode transfer informasi, yaitu memindahkan secara utuh pengetahuan guru ke pikiran siswa terutama untuk materi aplikatif seperti materi tentang listrik dan magnet. Guru mencoba memfokuskan pada upaya menuangkan pengetahuan yang dimilikinya sebanyak mungkin kepada siswa. Guru hanya mengejar materi dan takut kalau ada materi yang disampaikan tidak habis. Selain itu, kurangnya pemahaman konsep guru juga dapat menjadi kesalahan saat mengajar sehingga guru harus dibekali dengan penguasaan konsep yang baik (Septia Wahyuni,2019).

Hal ini berdampak pada kurangnya pengalaman langsung siswa dalam belajar, sehingga hasil belajar mereka kurang bisa ditingkatkan. Kondisi semacam ini dapat menyebabkan kegiatan belajar siswa menjadi kurang bermakna.

Handayanto (2003) menyebutkan, banyak faktor yang dapat membuat proses pembelajaran menjadi lebih menarik dan menghasilkan hasil belajar siswa yang tinggi. Salah satu faktor terpenting untuk hal itu adalah keterlibatan siswa secara aktif dalam proses pembelajaran. Siswa terlibat secara aktif dalam mengamati, mengoperasikan alat, atau berlatih menggunakan objek konkret sebagai bagian dari pelajaran. Untuk maksud tersebut, diperlukan langkah-langkah mendasar, konsisten, dan sistematik. Salah satunya penggunaan media pembelajaran yang tepat.

Media Pembelajaran adalah wadah dari pesan yang ingin disampaikan oleh guru kepada siswanya (Bambang Soenarko,2018). Hal ini dilakukan demi tercapainya tujuan pembelajaran yang ingin disampaiakan. Apabila media pembelajaran tidak dapat menjalankan fungsinya dengan baik, maka media pembelajaran dapat dikatakan tidak efektif.

Perlu pembiasaan bagi mahasiswa calon guru fisika untuk dapat mengembangkan teknik mengajar salah satunya dengan penggunaan media yang tepat. Namun banyak mahasiswa calon guru fisika belum dapat membuat media yang menarik terutama media tiga dimensi. Hal ini karena banyaknya biaya yang diperlukan dalam pembuatan media. Oleh karena itu perlu diadakan pelatihan pembuatan media yang menarik berbiaya murah (misalkan dengan memanfaatkan barang bekas) kepada mahasiswa calon guru fisika sehingga dapat memberikan transfer ilmu yang efektif dan efisien kepada siswa nantinya (Martala Sari,2018).

\section{SOLUSI/TEKNOLOGI}

Pembuatan media pembelajaran bertemakan listrik dan magnet sangat diperlukan untuk memberikan tambahan pengalaman kepada mahasiswa dalam membuat media interaktif tiga dimensi yang berkualitas. Ada dua alat yang dibuat sebagai media pembelajaran tiga dimensi yaitu motor listrik dan generator listrik. Kedua media tersebut diharapkan dapat memberikan tambahan ilmu bagi mahasiswa calon fisika dan tambahan pemahaman bagi siswa nantinya. Sasaran pengabdian kepada Masyarakat ini adalah mahasiswa Tadris Fisika Universitas Islam Negeri Mataram sebanyak 24 orang.

Metode yang digunakan dalam Pengabdian kepada Masyarakat ini adalah dengan metode ceramah untuk membahas teori dasar mengenai motor listrik dan generator listrik. Kemudian mahasiswa dibagi dalam 4 kelompok. Masing - masing kelompok diberikan magnet bekas dari sound system dan kipas angin. Masing masing kelompok diberikan waktu untuk merangkai media pembelajaran melalui praktek langsung oleh mahasiswa. Setelah alat dirangkai, masing-masing kelompok mempraktekkan media pembelajaran yang 
dibuat. Setelah masing-masing kelompok selesai mempraktekkan media pembelajaran dilakukan evaluasi melalui angket. Adapun rangkaian kegiatan pengabdian kepada masyarakat disajikan pada Gambar 1 .

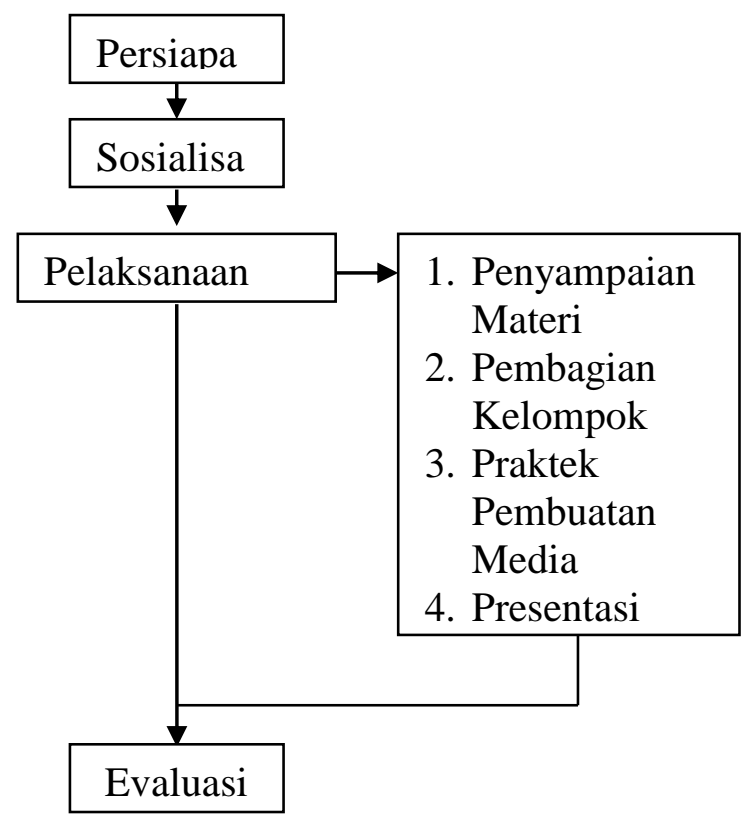

Gambar 1. Diagram Alur PkM

\section{HASIL DAN DISKUSI}

$\begin{array}{ccr}\text { Kegiatan ini } & \text { berbentuk } & \text { workshop } \\ \text { dimulai dengan } & \text { sosialisasi } & \text { kepada }\end{array}$

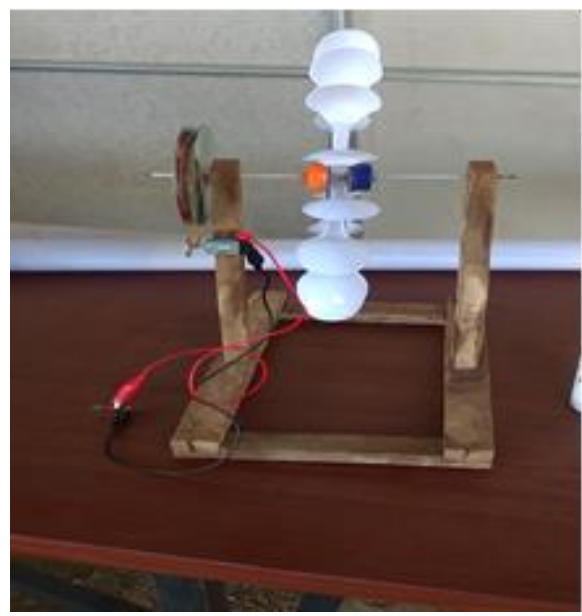

(a) mahasiswa Program Studi Tadris Fisika UIN Mataram. Kegiatan dimulai dengan pemberian materi mengenai motor listrik dan generator listrik yang dilakukan langsung oleh pengabdi. Selanjutnya pengabdi menyediakan barang bekas seperti magnet dari bekas sound system, dinamo kecil dari mobil tamiya, sendok plastik, papan bekas, dan dinamo bekas dari kipas angin.

Setelah penyiapan barang bekas dari pengabdi, mahasiswa kemudian dibagi menjadi 3 kelompok untuk membuat media pembelajaran bertemakan listrik dan magnet yang didampingi langsung oleh pengabdi. Setiap kelompok diberikan waktu untuk menyusun media pembelajaran yang diinginkan. Adapun Media Pembelajaran Hasil Kreasi Mahasiswa dari Barang Bekas ditunjukkan pada Gambar 1.

Kegiatan selanjutnya adalah presentasi yang dilakukan oleh mahasiswa. Masing-masing kelompok diminta untuk mempresentasikan dan menjelaskan media pembelajaran yang telah dibuat. Hal ini bertujuan untuk melatih mahasiswa dalam transfer ilmudan juga untuk eksplorasi pemahaman peserta berkenaan dengan media pembelajaran dari barang bekas yang telah dibuat (Bambang Soenarko,2018).

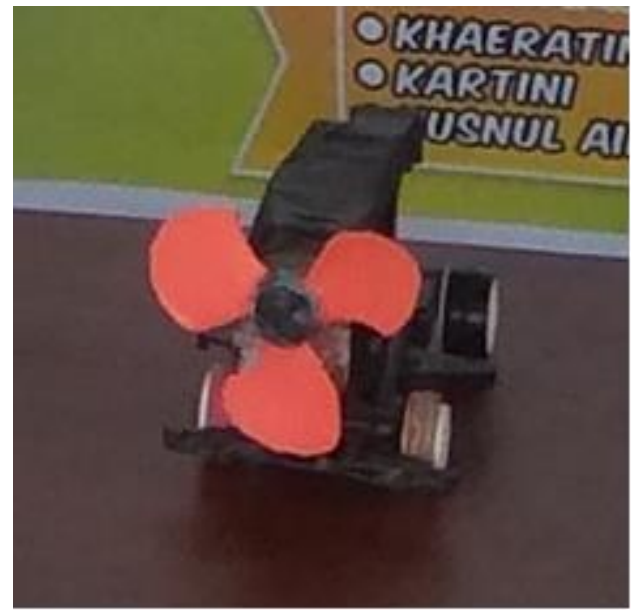

(b)

Gambar 2. Media Pembelajaran dari Barang Bekas Bertemakan Listrik dan Magnet Hasil Kreasi Mahasiswa (a) Generator Listrik, (b) Motor Listrik 
Kegiatan ini ditutup dengan refleksi yang berkaitan mengenai makna pelatihan pembuatan media pembelajaran dari barang bekas yang telah dibuat. Selain itu dibahas juga mengenai materi yang telah disampaikan sebelumnya.

Pada sesi terakhir dilakukan evaluasi dengan cara memberikan angket kepada peserta berisi tanggapan terhadap pelaksanaan kegiatan pengabdian kepada masyarakat. Angket berupa pertanyaan tertutup mengenai kebermanfaatan kegiatan, ketepatan waktu, dan ketepatan metode. Adapun hasil penyebaran angket ditunjukkan pada Gambar 3.

Berdasarkan hasil angket, semua peserta berpendapat bahwa kegiatan ini sangat bermanfaat. Namun sebanyak 15\% peesrta kurang setuju mengenai ketepatan waktu. Hal ini disebabkan karena minimnya waktu yang diberikan dalam penyusunan media. Banyak peserta menginginkan diberikan waktu lebih sehingga dapat menganalisis media pembelajaran yang sesuai dengan barang bekas yang disedian sehingga diharapkan media pembelajaran yang dibuat lebih maksimal baik dari segi tampilan maupun penggunaan.

Sedangkan dari ketepatan metode, hampir semua peserta menyatakan bahwa metode yang dilakukan sudah tepat. Adanya pemberian materi terlebih dahulu kemudian dilakukan pendampingan secara langsung memudahkan peserta dalam menysusn dan membuat media pembelajaran yang diinginkan. Adanya presentasi yang dilakukan oleh masing-masing kelompok dan masukan dari pengabdi dapat meningkatkan pemahaman mahasiswa mengenai media pembelajaran yang telah dibuat. Hal ini sangat bermanfaat ke depannya pada saat mahasiswa diberikan kesempatan mengajar di sekolah nantinya. Dengan penguasaan konsep yang bagus dan media pembelajaran yang memadai diharapkan transfer ilmu antara guru dan siswa dapat terjadi dengan baik. Hal ini untuk mengurangi kejenuhan peserta didik karena metode pembelajaran tanpa media cenderung konvensional sehingga pemahaman konsep dasar tidak maksimal (Eva Mulyani, 2018)

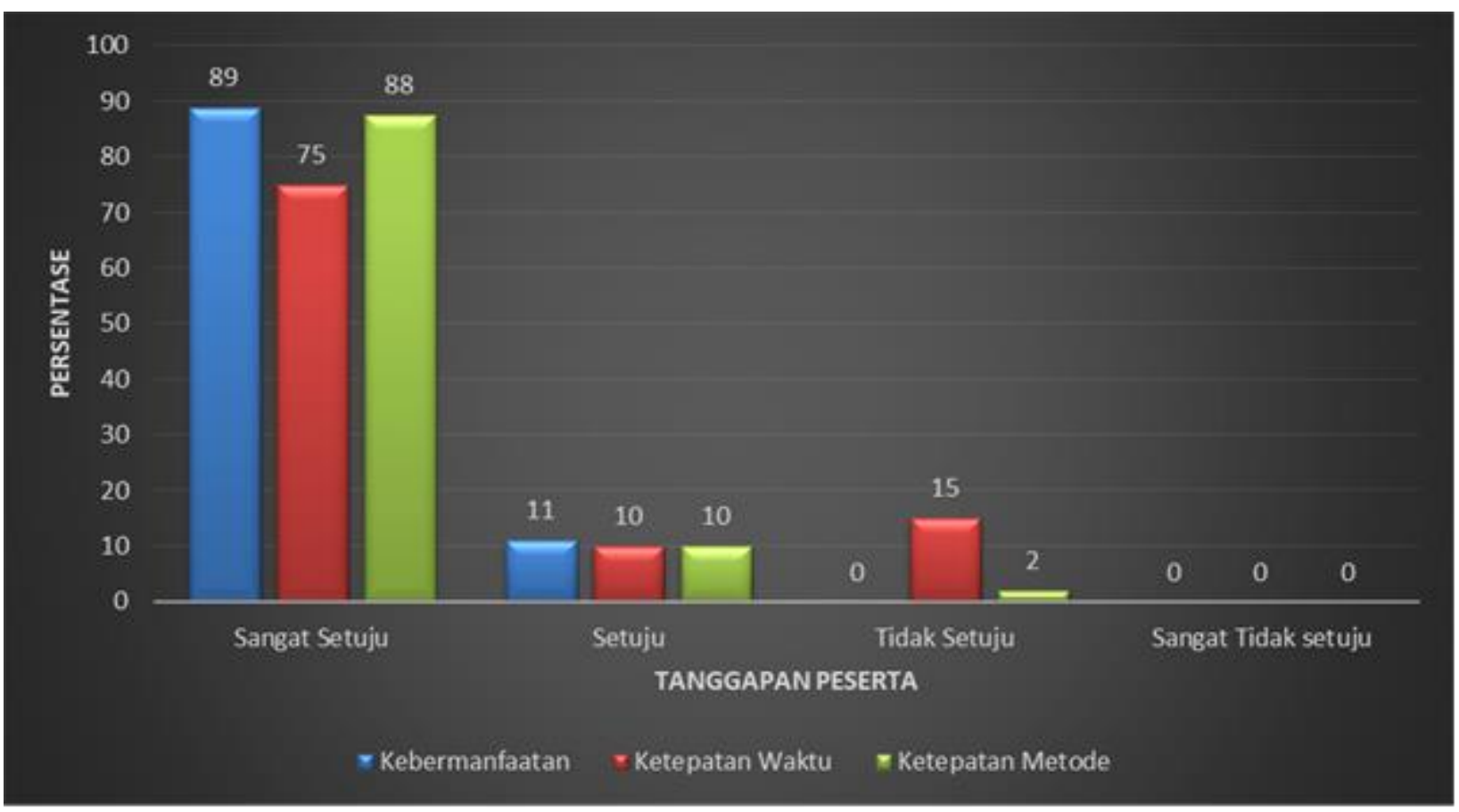

Gambar 3. Hasil Evaluasi Angket Peserta 


\section{KESIMPULAN}

Kegiatan pengabdian masyarakat telah dilaksanakan dengan sukses. Hal ini tercerin dari telah berhasilnya dibuat media pembelajaran mengenai generator listrik dan motor listrik dari bahan bekas. Selain itu hasil angket evaluasi menunjukkan bahwa sebagian besar peserta setuju akan kebermanfaatan kegiatan, ketepatan metode dan ketepatan waktu kegiatan.

\section{UCAPAN TERIMA KASIH}

Ucapan terima kasih diberikan kepada Ketua Program Studi Tadris Fisika yang telah memberikan izin pengabdian di Lingkungan Program Studi Tadris Fisika Fakultas Tarbiyah dan Keguruan Universitas Islam Negeri Mataram.

\section{PUSTAKA}

Septia Wahyuni dan Elfi Rahmadhani. 2019. Pelatihan Penggunaan Cabri 3 D pada Mata Kuliah Geometri. Jurnal Pengabdian Masyarakat MIPA dam Pendidikan MIPA. Volume 3 Nomor 1 Halaman 1-3.
Handayanto, S. K. 2003. Strategi Pembelajaran Fisika. Malang: UM Press

Bambang Soenarko et al. 2018. Pelatihan Pembuatan Media Pembelajaran Interaktif dengan Memanfaatkan Bahan Bekas untuk Guru Sekolah Dasar pada Anggota Gugus 2 Kecamatan Ringinrejo Kabupaten Kediri. Jurnal Abdinus, Vol. 1, No. 2, Hal. 96-106

Martala Sari, Sari Utami Lestari, dan Raudhah Awal. 2018. Peningkatan Keterampilan Mahasiswa dalam Pengelolaan Sampah Organik untuk Mewujudkan Green Kampus di Universitas Lancang Kuning. Dinamisia - Jurnal Pengabdian Kepada Masyarakat, Vol. 2, No. 2, Hal. 193-196

Eva Mulyani, Ike Natalliasari dan Siska Ryane Muslim. 2018. Implementasi Media Pembelajaran Berbasis Komputer dalam Pembelajaran Matematika. Jurnal Pengabdian Siliwangi, Vol. 4, No. 1, Hal. 80-84 